\title{
Kaempfers Lessons from Japan - Using Tokugawa Regulation for Educating Europe
}

\author{
Max Meulendijks
}

\section{Introduction}

Since Said's Orientalism (1978), travel writing scholars have focused on the tendency of Western travel writers to 'other' the peoples and cultures encountered on their travel. According to Thompson (2011), this concept of 'Othering' has two dimensions. First, it can refer to the way in which travel writers try to mark the differences between themselves and the people they meet. Second, it denotes a process by which authors highlight the inferiority of the people they meet by marking these differences between them (p.132).

During the "Age of Discovery", Europeans came into contact with a variety of different cultures from all over the globe. In Asia, they stumbled upon China and Japan, two welldeveloped countries, which were considered as civilized as those of Europe (Rietbergen, 2002, p. 64). The Dutch were the only European allowed into Japan, where from 1641 onwards, they were confined on the little artificial island of Deshima in the bay of Nagasaki (Rietbergen, 2003, p. 176). Here a company of approximately 20 men lived for a year or longer, under strict supervision of the guards, often without any proficiency in the Japanese language, with professional translators controlling all contacts of these foreigners with Japan (ibid, p. 181).

Consequently, these Europeans had a monopoly on the representation of Japan. One 
of the most notable works on Japan of this era was The History of Japan by Engelbert Kaempfer.' Although the work contains 'Othering', neither of Thompson's definitions would be encompassing. In line with the European realisation that these cultures were equally civilized, I argue that Kaempfer's work notes the differences between Japan and Europe to highlight the faults of Europe. ${ }^{2}$

Constrained by both time and space, this chapter mainly discusses Kaempfer's writing on the regulation of Japan, more specifically, the regulation as it was imposed by the shoguns of the Tokugawa dynasty. ${ }^{3}$ That subject is chosen because Japan's isolation and generally harsh laws, which were the result of Tokugawa rule, were of particular interest to his European readership (Michel, 2000, p. 111). Regulation here refers to the manner in which the Japanese government sought to exert control; it encompasses law-making, regulation of foreigners and the actions of the Japanese people under regulation. Thus, this chapter addresses the way in which Kaempfer used Tokugawa regulation as a lens for describing the Other, and how this Other was used to express Kaempfer's personal beliefs.

Recent studies have shown that The History was not just by the hand of Kaempfer, and that the book's translator, Johann Caspar Scheuchzer, had adapted the work, emphasizing criticism and weakening appraisal. Based on this adapted work, Rietbergen (2002) argues that the work's scholarly distance and emphasis of Japanese uniqueness precluded a comparison between Europe and Japan (p. 77). However, to analyse Kaempfer's personal beliefs, such an adaptation does not suffice. Hence, a new English translation of the original manuscript by Bodart-Bailey (1999) Kaempfer's Japan: Tokugawa Culture Observed is used, checked with Michel \& Terwiel's German translation Heutiges Japan (Kaempfer, 2001). ${ }^{4}$ Therefore, a second point of research is how Kaempfer's original manuscript was adapted by Scheuchzer to reflect different ideas.

1 This is a shortened version of the title, in full it was named: The History of Japan, giving an Account of the ancient and present State and Government of that Empire; of Its Temples, Palaces, Castles and other Buildings; of its Metals, Minerals, Trees, Plants, Animals, Birds and Fishes; of The Chronology and Succession of the Emperors, Ecclesiastical and Secular; of The Original Descent, Religions, Customs, and Manufactures of the Natives, and of their Trade and Commerce with the Dutch and Chinese. Together with a Description of the Kingdom of Siam.

2 Although references throughout the chapter deal with the English version, it should be noted that the arguments were originally based on the 1729 Dutch translation De Beschryving van Japan, available in the Jesuit library of Maastricht University. The switch to the English version was made later in the process to prevent any mistakes on my part, in translating from the Dutch book to this English chapter.

3 The military ruler of Japan.

4 The Kaempfer's Japan is used to have a better comparison with the original English translation, but since this version is sometimes incomplete, or may have had to rephrase Kaempfer to accommodate the English language, the Heutiges Japan was checked in cases where there was uncertainty on parts of the text. 


\section{Kaempfer's life}

Engelbert Kaempfer (1651-1716) was born in Lemgo, in the County of Lippe, Germany, son of a Lutheran vicar. Although the Thirty Years' war had ended three years before he was born, its after-effects were still noticeable. Poverty and hunger still thrived, but his father was in a sufficiently strong position to send his sons to a good school (Haberland, 1996, p. 6). When Kaempfer was in his early teens, Lemgo experienced a violent witch hunt, which lasted for several years. His father had initially supported this persecution, although he withdrew this support when he realized it was the city council's way of disposing of their enemies (Bodart-Bailey, 1988, p. 6). His father's brother-in-law did the same, and was executed for his actions in 1665 . It is hardly conceivable that Engelbert was unaware of these events (Haberland, 1996, p. 7).

After pursuing the Athenaeum at Danzig in 1672-73, Kaempfer kept on studying, first at Cracow until 1676, and later at Königsberg and Uppsala. He studied a variety of topics, although medicine and philosophy were the main components. Furthermore, Haberland (1996) argues that Königsberg was a centre of Swedish influence, which might have caught Kaempfer's interest, as it showed him the kind of power King Charles XI of Sweden possessed (p.13). At Uppsala, with his talents, and through his connections in Stockholm, he gained the position of secretary in a delegation to the Persian Shah in 1683 (ibid, p. 18). Although such travels were not without dangers, they brought with them great opportunities for advancing careers, either politically or scholarly (ibid, p. 15).

When the time came for the Swedish delegation to return home, Kaempfer did not return with them. As Kaempfer himself argued in the preface of The History, this was mainly related to the 'train of calamities' Germany was involved in at that time, such as the war with Louis XIV (Kaempfer, 1727, p. i). However, Bodart-Bailey (1988) notes that there were also arguments of a more scholarly nature. There had been reports on Persia before, and Kaempfer did not feel his own notes would contribute to a whole new understanding of the country; countries further eastward offered much larger opportunities in this regard (p. 2). Moreover, Kaempfer knew Java as a botanist's paradise, as he had corresponded with two fellow physicians with an interest in botany, who resided in Batavia (ibid, p. 3). Through the officials he had come to know during his stay in Isfahan, he applied for a position in the Dutch East India Company, or VOC in 1684 (Haberland, 1996, p.39). It was not unusual for the VOC to have Germans in their employ, as their crews were often quite international (Van Gelder, 1997). Foreigners were especially wanted for medical positions, because the Dutch Republic could not fill the vacancies on its own (Bruijn ,2009, p. 182). Kaempfer considered this employment to be "less honourable", but as he was not a man 
of high means, his options for further travel were clearly limited (Kaempfer, 1727, p. i).

After some years serving at postings in the region of the Persian Gulf and India, Kaempfer arrived at Batavia, the capital of the VOC in Asia, in 1689. There things did not go as planned. Assigned physician duty on the harbor island the Onrust, Kaempfer had little time for the kind of work that characterized his previous journeys (Bodart-Bailey, 1995, p. 23). Stuck in an awful working environment, he wrote to a fellow physician, Herbert de Jager, with whom he had corresponded in Persia, hoping that he might receive much needed support for more favorable medical positions in Batavia (ibid). By 1689, a helping hand arrived in the form of Johannes Camphuis. Camphuis had been posted on Deshima himself three times, and it was clear that the man loved everything Japanese, having a Japanese villa built in Batavia, and eating Japanese food every Thursday (ibid, p. 22). As the VOC's governor-general of the Indies, Camphuis was in a position responsible for the whole of Asian trade, and had the authority to sufficiently help Kaempfer in his studies. Although Camphuis gave this private support to Kaempfer, he never formally hired him through VOC means to write his book. According to Bodart-Bailey (1995), Kaempfer's access to the diaries of Deshima's opperhoofden ${ }^{5}$ and the outpost's yearly financial reports was unusual for a physician of such a low status, and was likely the result of Camphuis's support (p.28). The support is further evidenced by Kaempfers possession of confidential documents issued by the VOC, and some Japanese materials carrying notes not by his hand (pp. 29-30).

Both in Europe and Batavia, more information was wanted on Japan. Often people relied on texts written by people living in Japan before the exclusion of foreigners, such as Jesuit missionaries. Another source of information were reports or diaries by employees of the Dutch-East India company. However, little of this information was actually published by the VOC, a matter which aroused criticism from Europe's scientific community (Rietbergen, 2003, p. 186). Some information out of these diaries was used in compiled volumes made by European scholars, (such as Arnoldus Montanus), even though these scholars had never visited Japan themselves (Bodart-Bailey, 1995, p. 30). To improve that situation, Camphuis send Kaempfer to Japan in 1690. 


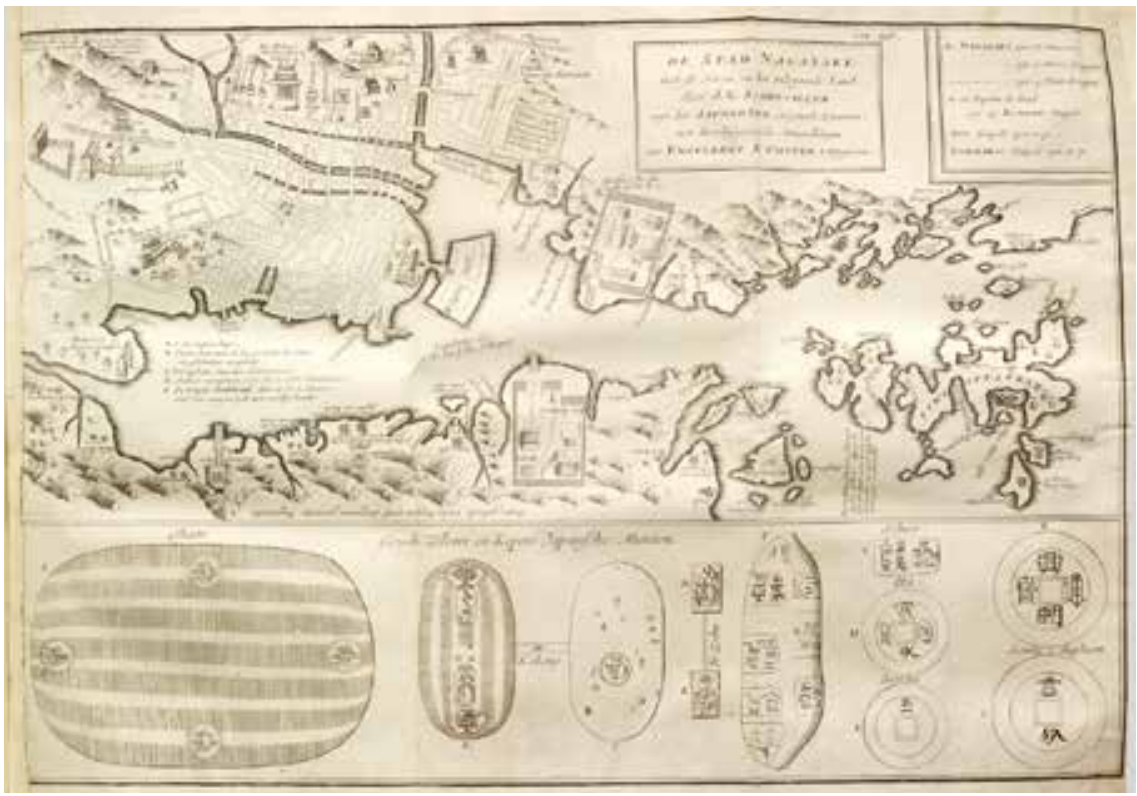

Fig. 1: Map of Nagasaki and Deshima (island right of the town, linked by a bridge); and pictures of Japanese coins.

Source: Kaempfer, E. (1729). De Beschryving van Japan: behelsende een verhaal van den ouden en tegenwoordigen staat en regeering van dat ryk. 's Gravenhage: P. Gosse en J. Neaulme \& Amsterdam: Balthasar Lakeman, pp. 180-181.

Clearly, the scarcity of information must have been a reason for Camphuis to support anyone who could write a book on Japan, but why a physician like Kaempfer? In Nagasaki, the Dutch opperhoofden were too exposed to put themselves in a position from where to actively study the Japanese, while the other personnel had too little education, interest and time to concern themselves with these manners (Michel, 2010, p. 114). The factory doctor however, had only to keep the handful of men on Deshima healthy, and was thus confronted with ample time to spend on information gathering activities. With his university education and proficiency in observation, Camphuis considered Kaempfer to be the best man for the job (Bodart-Bailey, 1995, p. 30).

Of course, spare time was not sufficient for gathering information, it was also necessary to find methods for procuring and translating Japanese information without the interference of the many guards. Kaempfer notes the help he received in his task from 
a "discreet young man", without whom he could not have written his work (Kaempfer, 1727, p. iv). This young man, Imamura Genemon Eisei (1671-1736), was born into an interpreter family, had started learning Dutch from a young age, and had been allowed access to Deshima from the age of 10 (Van der Velde, 1995, p. 45). Assigned to Kaempfer as an assistant, Genemon was eager to learn, and happily supplied Kaempfer with every text he desired, also taking efforts to translate and explain everything his master wanted to know (Kaempfer, 1727, p. iv).

Although Kaempfer wrote on a lot of different topics, the way he filled his days at Deshima in 1690-92 is unfortunately unknown. Although he describes periodical events, he never goes in depth about the manners in which daily life was structured on the island, and there seem to be no sources describing this, until the end of the $18^{\text {th }}$ century (Rietbergen, 2003, p. 219).

After two years at Deshima, and twenty-seven years away from home, Kaempfer returned to Europe, arriving in Amsterdam in 1693, and returning homeward in 1694 (Haberland, 1996, pp. 83-89). Here, he planned to edit his notes on Asia into book form, including cross-referencing his notes to the works of other scholars (ibid, p. 89).

Unfortunately, several factors kept him from this work. First of all, he became physician to the Count of Lippe in 1698, in order to make ends meet (Ibid). Second, as the tales spread of a doctor with a lot of experience in and curiosities from Asia, Kaempfer had to entertain many visitors. Dismissing them was not always possible, because some of these guests were of high status (Ibid, p. 90). Third, his marriage to Maria Sophia Wilstach in 1700 was far from a happy enterprise. More of an arrangement, it appears Kaempfer had hoped that the dowry from his rich family-in-law would make work unnecessary, and allow him to completely focus on his work (Ibid, p. 91). Lastly, he encountered some troubles in obtaining the scholarly books necessary to complete the editing of his work. With all these troubles, it eventually took Kaempfer 18 years to complete his Amoenitates Exoticae, published in $1712 .^{6}$ This work, over nine hundred pages long, encompassed many observations, on multiple countries, which he had made on his journey through Asia. Although one of its five sections dealt exclusively with Japanese flora, it contained little information on the general state of the Japanese country and its people, and served mainly to entice its readers for Kaempfer's other manuscripts (Bodart-Bailey, 1999, p. 7). However, at his death in 1716, his other manuscript on Japan was left unfinished (Haberland, 1996, , 92).

6 English translation would be Exotic Pleasures. 


\section{Publishing The History}

After Kaempfer's death, this manuscript fell into the hands of Johann Herman Kaempfer, his nephew, who took care of him in his final days. Sir Hans Sloane (1660-1754) had read Kaempfer's Amoenitates, in which it was made clear that the doctor was in possession of both Asian curiosities and a manuscript for another book on Japan (Haberland, 1996, p. 94). Apart from being the physician to the royal family, and secretary of the Royal Society, (president of said society from 1727 onwards), Sloane was known as a fervent collector of books, fossils, plant and animal specimens, and many other objects worth collecting (Michel, 2010, p. 105). After his death, these collections got into the hands of the state, and laid the basis for the collections of the British Museum

At first, Sloan relied on Philip Henry Zollman, secretary to the secretary of state, for the recovery and translation of Kaempfer's manuscript. Unfortunately, requests by the British government to do work abroad kept Zollman from his translating duties, and Sloan requested him to give up the job, and deliver the manuscript to him (Massarella, 1995, pp.109-110). Well aware of the manuscript's value, and therefore wishing to move on quickly, Sloane picked his young Swiss librarian, the 24-year old Johann Caspar Scheuchzer to be the new translator of the work in 1725 , and Scheuchzer gladly took this great opportunity upon himself (Ibid, p. 112; Michel, 2010, p. 116).

Johann Caspar (1702-1729) was the son of Johann Jakob Scheuchzer, a man of many talents, but especially interested in physico-theology, or proving the bible's value by utilizing natural sciences (Michel, 2010, p. 103). It is clear that Johann Jakob had plans for his son to enter the world of science as well. When Johann Caspar was only 5 years old, his father already mentioned him as taking part in his observations on a lunar eclipse, which he submitted to the Royal Society of London. Furthermore, Scheuchzer's dissertation focuses on Diluvianism ${ }^{7}$, which was one of his father's favourite subjects (ibid).

Johann Jakob decided to send his son to England, to John Woodward, a doctor, and fellow to the Royal Society of London in 1722. After Johann Caspar and Woodward had gotten into an argument over the latter's inability to offer the young Scheuchzer some respectable work to do, Hans Sloane decided to let him live at his house instead, putting him to work in his library (ibid, p. 107-108). Apart from Kaempfer's manuscript, Scheuchzer created a catalogue for Sloane's library, and contributed to the Philosophical Transactions, the official journal of the Royal Society; in addition, he researched vaccinations of smallpox (Ibid, p. 108-110). After two years of translating by Johann Caspar, Kaempfer's manuscript

7 A theory seeking to explain geological phenomena from the assumption of a universal flood. 
was finally published in 1727. Although a promising beginning of a scientific career, Scheuchzer had become increasingly sick over the years, dying already in the beginning of 1729 (Ibid, p. 111).

\section{Description of content}

In line with the rules of the Ars Apodemica, or the conventions of travel writing, The History uses a conventional scheme (Rietbergen, 2002, p. 74). Book 1 deals with the general state of Japan, both geographically and politically. It also contains chapter on both the 'true' origins of the Japanese as concluded by Kaempfer, and the 'fabulous' origins, as stated by the Japanese themselves. Lastly, this book deals with the climate, minerals, plants, animals and fish of Japan. Book 2 focuses on the political state of Japan, although its six chapters exists mostly out of lists containing the names of the different gods, emperors and shoguns who have ruled Japan over the centuries. Book 3 deals with the state of religion in the country, providing an overview of the general religious history, as well as more in depth information on Shinto and others. Book 4 deals with the situation in Nagasaki. Its chapters describe the city itself, as well as its government, its regulation of the streets, its temples, and the history of Portuguese, Dutch and Chinese trade with Japan. Lastly, Book 5 deals with Kaempfer's travels to the Imperial court at Edo (now Tokyo).

Based on Kaempfer's notes, an extra chapter was added to book 1 on his short stay in the Kingdom of Siam. Furthermore, Scheuchzer believed several chapters in Kaempfer's previous Amoenitates Exoticae (such as chapters on tea making, medical practices of Japan, and an influential enquiry on Japan's policy of seclusion) to be of great interest to the subscribers of the book, and added them accordingly. 


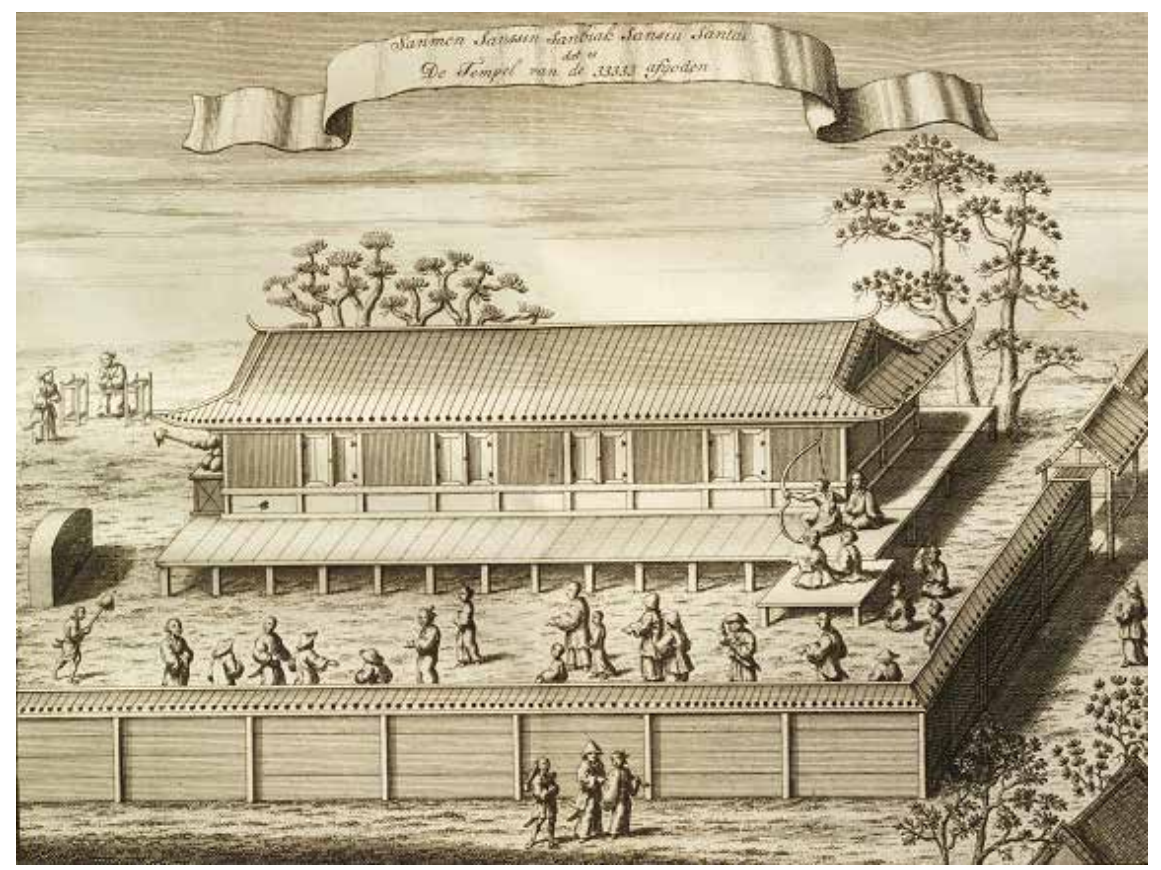

Fig. 2: The Temple of the 33333 Idols.

Source: Kaempfer, E. (1729). De Beschryving van Japan: behelsende een verhaal van den ouden en tegenwoordigen staat en regeering van dat ryk. 's Gravenhage: P. Gosse en J. Neaulme \& Amsterdam: Balthasar Lakeman, pp. 396-397.

\section{Tokugawa practices vs. European conventions.}

On the topic of regulation, book 4 and the last enquiry into Japan's policy of seclusion seem most important. Hence, these are the chapters that are focused on, although the occasional references to regulation in other parts are also used. For the main part, a comparison is made between Kaempfer's original and the English version, to show how Scheuchzer's adaptation changed the tone of the work. A comparison between the chapter on seclusion and Scheuchzer's version is not made, as this chapter was not included in Kaempfer's Japan or Heutiges Japan, and had already been published separately by Kaempfer, before Scheuchzer started his translation. 
In his enquiry on the Japanese policy of seclusion, Kaempfer began his case with a lengthy introduction to the many arguments to be had against said policy. Surely, he suggested "to shut up the Empire [...] keep the natives as it were, prisoners within the bounds of their own Country [...] What is it else but breaking through the laws of nature, and the All-wise order, which the Supreme Being established in the world" (Kaempfer, 1727, Appendix, p. 53)

This negative introduction is clearly a rhetorical device used by Kaempfer. He was not introducing his actual findings, for those are much more positive. Laws and authorities were obeyed as they should, and the Japanese lived in a state of happiness, peace and unity. In fact, Kaempfer noted that the country "was never in a happier condition than it now is" (Ibid, p. 75). This must have been an attractive prospect for a man whose country was constantly embroiled in war.

In addressing the counter-arguments, Kaempfer was speaking to his European audience, affirming their expectations and assumptions. As a result, Kaempfer's conclusions were not just aimed at creating a more positive assessment of the Japanese state of affairs, they are also intended to criticize the conventional assumptions of Europeans.

The most explicit comparison was between the processes of law in Europe and Japan. Positioning himself against European prejudices, he claimed that while the Japanese could be considered to know less about the science of law than Europeans do, this works to their advantage (Ibid, p. 64). Back home, he argued, the road to justice is long, and can thus easily be abused. The many writings and procedures made lawsuits tedious and expensive, the existence of higher courts multiplied these problems even further, so that "having escaped the Charybdis, they are swallowed up by the no less dangerous Scylla" (Ibid, p. 64). Instead of protecting the innocent, it led to increasing problems and burdens for all parties involved. With the Japanese system, such complicated procedures did not exist. They may have made mistakes in particular cases, but overall he considered it much less problematic, and more effective for ruling the country.

The concept of fining, quite ordinary in Europe, was also criticized, as this led to an asymmetrical and unfair application of punishment. The Japanese believed that fines would allow the rich to simply pay off their life of vice; Kaempfer concurred that such a situation would be absurd (Kaempfer, 1999, p. 160). The fact that the Japanese only condemned to torture or execution also increased fairness; this provided clarity about possible punishment, and consequently, "no body can plead ignorance of the penalty, or complain of any wrong done him" (Kaempfer, 1727, Appendix. p. 68).

The Japanese habit of not only punishing the offender, but also those in his direct environment, was also of interest to Kaempfer. When a person had died as a result of a 
street brawl, all people directly involved would be put to death, even if they had acted out of self-defence (Kaempfer, 1999, p. 162). Moreover, the people living in the three houses closest to the event were locked in their houses for a period of time. The guardsmen, bystanders and heads of households were to be punished, especially when there was evidence that they could have stopped the crime, or had enough evidence to expect it was going to happen, but did not act to prevent it. Apparently, Kaempfer expected this policy to be criticized by his European audience as he defended Japanese policy with a quote from Canon Law: "He who neglected to prevent a crime when he could have is beyond doubt guilty of the same crime" (Ibid, p. 162).

On his way to Edo, his party came across several public execution grounds. After a general description of their aesthetics, he opened the discussion by noting the conventional wisdom that "many laws result in many criminals" (Ibid, p. 258). However, with the description that follows, he undermined this statement. Although the Japanese legislators sought to prevent any possible crime by continuously creating new laws, the crime levels were not that high in Japan, in fact, the Japanese could lay claim to having less convictions and bloodshed than the Christian countries (Ibid, p. 258). In the enquiry, a similar argument is made, but with a stronger comparison to Europe. Since the Japanese shogun can make any law he pleases, laws are severe and numerous. However, they are not difficult to obey, promote the general good, and preserve the kind of government, which is most favourable to that good (Kaempfer, 1727, Appendix, p. 68). Moreover, the Japanese authorities inform the public well, hanging up tables describing any new laws throughout the Empire (Ibid, p. 68). Therefore, he argues, they cannot be considered as similar to the tyrant Dionysius, who made his laws out of cruelty, and kept them out of people's sight, thereby contributing to a high number of offenders and executions .

Both in rhetoric and philosophy, Dionysius was given characteristics of the typical textbook tyrant (Westlake, 1959, p. 269). By highlighting the difference between the Japanese and Dionysius, Kaempfer attempted to persuade the reader that against European expectations, a multitude of severe laws is not necessarily problematic, even if the monarch could make any law he pleased. In fact, he asserted that a monarchy, when above the law, is most favourable to the general good, thereby appraising the idea of absolutism.

Partially, this positive appraisal of absolutism and the severity of the law was related to the tartaric nature of the Japanese according to Kaempfer. Considering the Japanese situation to be similar to that of Russia, he noted that a people as stubborn and unruly as 
the Japanese, needed such strict laws to keep Japan in a state of peace ${ }^{8}$ (Kaempfer, 1727, Appendix, p. 68). How else to keep these "obstinate tartars" under control, than through the fear of death (Kaempfer, 1999, p. 259). However, there is also evidence that Kaempfer's prescription of absolutism was not purely focused on the Japanese situation, but that they reflected more general ideas on the role of government.

Brakensiek (2002) notes that already at age twenty-two, Kaempfer wrote a political treatise dealing with the question of whether sovereignty had to be divided between a prince's personal power, and the non-personal authority derived from the constitution of monarchy (p. 228). The young Engelbert pleads for an undivided sovereignty, concluding with Bodin's 'Majestas est Legibus solute Potesta', or the sovereign is not bound by the law (ibid, p. 229).

Furthermore, Bodart-Bailey (1999) suggests that his appraisal of absolutism is likely to be the result of his personal experiences as a young man in Germany, such as the time his uncle ran into conflict with the city council (p. 17). In his description of Japanese history, the "Princes of the Empire" (as in noblemen) are presented as the main antagonists, secretly revolting and using their power against public peace (Kaempfer, 1727, Appendix, p. 67). The government cannot function, unless these Princes are subdued, and their obedience is secured. A similar dislike of nobility is present in Kaempfer's ideas on the European situation. In a personal letter, he wrote: "We Germans are, as is well known, the slaves of our barons." (Bodart-Bailey, 1999, p. 18). Thus, in analyzing the Japanese situation, Kaempfer seems to be ventilating his thoughts on the European state of affairs as well.

\section{Negative about Nagasaki}

Kaempfer appraised the Japanese manner of regulation, and used it point out the weaknesses of the European system. However, this does not mean that Kaempfer never showed criticism on Japanese regulation. Concerning the situation at Nagasaki, he took a less comparative standpoint, and occasionally lashed out at the bad practices confronting him. When we take into account that the Dutch were imprisoned on a small island, under constant surveillance by the Japanese, such complaints are not entirely unexpected.

8 The comparison to Russia may come across as negative, as during Kaempfer's time the country was (like China) identified with despotism; a form of rule which was strong, but would also necessarily entail "degeneration" (Brakensiek, 2002, p. 227). However, Kaempfer himself notes that Japan is unlikely to "degenerate" in this way, despite its long state of tranquillity, because the Japanese mindset stops this from happening (Kaempfer, 1727, Appendix, p. 58). More on this mindset is provided in the final section, although lack of space prevents it from being fully engaged with. 
However, this criticism cannot automatically be considered to undo Kaempfer's positive view of Japanese society, without first putting such criticism into context.

A returning problem was the trickery of officials, who always discovered new ways to capitalize on foreign profits. In addition, Kaempfer was clearly annoyed by the fact that they were treated like "criminals, traitors spies, prisoners" (Kaempfer, 1999, p. 191), by translators who served as "sworn enemies", (p. 197), and the "heavy expenses, and also by the throng of guards and inspectors," which seemed to accompany any action of the Dutch (Ibid, p. 191). For guards paid by the Dutch, Kaempfer's main criticism seems to be that many of these staff members try to take profit from the Dutch in an unfair manner (Ibid, p. 192).

Moreover, Kaempfer found it important to stress that while some guards were paid by the Japanese, and others by the Dutch, in the end they both served the Japanese, and must be regarded as their "sworn guards, and secret enemies" (ibid). At other times, Kaempfer's judgment of the guardsmen was more positive, as a later statement on the Otona ${ }^{9}$ shows. Although this man was severely disliked by both the Dutch and himself, Kaempfer did concede that the man was actually an honest man, without the slightest intent of misbehavior, and well versed in the teachings of Confucius (ibid, p. 193). Moreover, he stresses that even though this person is obliged to investigate the Dutch, and keep them in line, he has never taken any steps against the Dutch on his own accord, only if they violate the shogun's orders.

This linkage between the Otona's good behavior and his loyalty to the shogun, points to an important distinction in Kaempfer's writings. On multiple occasions, Kaempfer emphasized the differences between Nagasaki on the one hand, and Japan as a whole on the other. Before describing the plunder habits of the guards, he called them the "riffraff of Nagasaki" (Kaempfer, 1999, p. 199). His observations on the lack of bloodshed in Japan as a whole were immediately followed by the disclaimer that these praises were not applicable to Nagasaki (ibid, p. 259), and the foreign trade unique to his city was considered the cause of its hardship and anxiety (ibid, p. 165). As a consequence, Kaempfer's negative experiences in Nagasaki seem restricted, the result of the city's foreign trade, and should not be seen as indicators of the general state of Japan, which was happily isolated.

This distinction between Nagasaki and Japan was weakened in Scheuchzer's version as a result of his normative additions to Kaempfer's observations. The latter observes that the regulation of Deshima was what the Dutch would have to be satisfied with in Japan

9 The overseer of a certain street, or in this case, Deshima. He is responsible for enforcing the regulation of the area under his control, and serves as its magistrate. In Heutiges Japan, the term "Wiekmeister" is used (Kaempfer, 2001, p. 265). 
(Kaempfer, 1999, p. 190). The former added to this observation that "there being no hopes that we should ever be better accommodated, or allowed more liberty by so jealous and circumspect a nation" (Kaempfer, 1727, p. 326). Kaempfer's neutral observation was turned into a critique of the general Japanese mentality by Scheuchzer. Similar additions focusing on the "jealous circumspection, which is peculiar only to this Nation" (Ibid, p. 94) ${ }^{10}$, can be found running throughout the translation. Emphasis was also put on the guards trying to cause problems for the Dutch whenever possible (Ibid, p. 330). Moreover, he argued that any good behavior from these guards is to be feared even more, as he believes signs of good will are nothing but a veil, which hides the true "hatred and enmity" underneath (Ibid, p. 330). In Kaempfer's version, this concept of good behavior being a veil is not present.

Although Kaempfer was displeased with certain aspects of Japan's regulation, his criticism was localized to the situation at Nagasaki, and thus not representative for any problems related to Japan as a whole. By adding references to negative characteristics, such as jealousy, to Kaempfer's observations, Scheuchzer did give the impression that this criticism should be considered applicable to the entire country.

\section{The stoic Tartar}

Of the two Asian civilisations, Kaempfer considered the Chinese to be peace loving and calm, while the Japanese were considered to be more 'Tartaric', like the Mongols or Turks, being warlike, passionate and impulsive (Kaempfer, 1727, Appendix, p. 58-59). The Japanese were also considered unruly and prone to revolt (Ibid, p. 66). Hence, it is not surprising that authors such as Rietbergen (2003) argue that Kaempfer's assessment of the Japanese nature was negative (p. 223).

In Kaempfer's observations on the behavior of the Japanese undergoing regulation, his assessment seems quite different. When dealing with executions for instance, Kaempfer gave a positive assessment of the manner in which the Japanese undergo execution or escape it by committing suicide. Faced with two men to be beheaded, he noted the "well spoken"11 conversation between the two convicts (Kaempfer, 1999, p.223). When the elderly convict started a prayer, the younger one scorned him for it, saying that this

10 This particular instance describes how shipwrecks are dealt with (Kaempfer, $2001 \mathrm{p}$. 76). The chapter in which the description is placed is unavailable in Kaempfer's Japan, hence, it was compared with Heutiges Japan, and this statement is not present there. 
prayer would do them no good, and serve only to show the elder's cowardice to the Dutch. Later, he described the suicide of a Japanese smuggler as "heroic" (Ibid, p. 391). In addition, he noted that despite the many hardships faced by the Japanese, they remain civil and well mannered (Kaempfer, 1727, Appendix, p. 59). He did not seem to pity the Japanese for having to face these hardships, or condemn them to it because of their nature; he respects them for being able to face them with such courage.

Compared to his description of origins of the Japanese, this sounds surprisingly positive. A passage from the enquiry sheds more light on where this new assessment might have come from. Here, Kaempfer argued that the Japanese were an heroic people, who were willing "with an undaunted stoicism, to lay violent hands upon themselves" when they were in situations of submission, or in circumstances outside of their control (Kaempfer, 1727, Appendix, p. 56).

The interesting addition here is the word stoicism, a reference to a Greek/Roman philosophical tradition. Bodart-Bailey $(1988,1999)$ emphasises the link between Stoicism and Confucianism in Kaempfer's writings on religion in Book 3. In Scheuchzer's version, any comparison between the two was removed, but to Kaempfer, the secular Confucian teachings were equivalent to those of Seneca and the Ten Commandments (Ibid, 1988, p. 19). According to him, the similarities held both in terms of content, and scale of influence. Thus, to understand Kaempfer's assessment, it is useful to shortly explain the basic tenets of Stoic thought.

Julius Lipsius' De Constantia is an example of the neo-stoic tradition, which became very popular in the $17^{\text {th }}$ century (Bodart-Bailey, 1999, p.19). The term Constantia referred to an immovable strength of mind, an inner perseverance which would lead men accept life the way it is presented (Van de Bilt, 1946, p. 29). The basis of this strength was considered to lay in reason, and the ability to rightly assess the value of things. For instance, money and health were "indifferents", possessing them did not matter for deciding whether someone was virtuous or sinful (Baltzly, 2012). Although it is not wrong to have them, they should never stand in the way of a virtuous life, and they were otherwise of no relevance to any reasonable assessment of the best moral choices; a person must be indifferent to them. A particular focus here should also be given to the stoic views on suicide, as this is important in explaining Kaempfer's positive assessment of the act. For most stoics, if circumstances made a virtuous life difficult or impossible, suicide was considered a viable moral choice (Seidler, 1983, p. 431). Seneca went one step further; he prescribed suicide both for escaping a forced life of vice, and as an act of freedom, which is possible even under the greatest of constraints: "a wise man lives as long as he ought, not as long as he can" (Rist, 1969, p. 247-249). That the Japanese are willing to face death valiantly in 
similar circumstances, sometimes actively through suicide, can therefore be seen as an expression of their perseverance, and stoic wisdom.

In Scheuchzer's version of The History, this positive perspective seems to be less consistently applied. In a chapter on the regulation of the Japanese population, Kaempfer discussed the manner in which quarrels in the street are addressed. When two people fight in the street, and one died, the other had to be sentenced to death, regardless of his role in the matter, even if he was only defending himself. The section was given a normative addition by Scheuchzer, as it was said that "All he can do, to prevent the shame of public execution, is to make away with himself, ripping open his belly. Nor is the death of such an unhappy person satisfactory, in their laws, to atone for the deceased's blood" (Kaempfer, 1727, p. 286). The words 'all he can do' signified a fatalism on part of the Japanese, and the reference to the 'unhappy person' drove the point further home that this was not how it should be. When we take a look at Kaempfer's original statements on this issue, the wording chosen is less negative. Apart from a noting that the person in question may "forestall this disgrace by disembowelling himself" (presenting it as a possible choice, rather than a determined outcome), Kaempfer gave no actual judgement on this issue (Kaempfer, 1999, p. 162). Previously mentioned references to Japanese heroism were also removed by Scheuchzer, and replaced by references to their desperation (Kaempfer, 1727, pp. 559-561; lbid, 1999, pp. 389-391). Even though Kaempfer used punishments as a marker of his respect towards the Japanese, Scheuchzer changed this into pity, and thereby a condemnation of Japanese law.

When discussing the foreign powers, Kaempfer was much more critical of the way in which both the Dutch and the Chinese were reacting towards Japanese regulation. The Dutch had been put in a situation where they had to live in imprisonment, unable to show any sign of their Christian religion. Although a more negative view of Japanese policy seems to shine through, this small criticism was greatly exaggerated by Scheuchzer, who continuously described the policy as a sign of jealousy of the Japanese nation. Consequently, in the latter version, the Dutch seemed much more the victims. As Kaempfer's tone is more neutral, the feeling of Dutch victimhood was much weaker, and his eventual negative assessment of their behavior hit home much harder. The Dutch willingly live in a situation of constraint, precluded from doing their religious duties, under conditions which are "an affront to any high minded soul", only because they can make a lot of money (Kaempfer, 1999, p. 188). A similar argument was made when describing the Chinese traders in Nagasaki, with Kaempfer directly comparing the Chinese love for profit with that of the Dutch (Ibid, p. 226). Later in the text, he argued that the lust for profit is also the reason so many Japanese in Nagasaki sought to transgress the law (Ibid, p. 259). 
These groups submitted to conditions which made a virtuous life difficult, solely for the love of gold and profit. However, these were considerations a Stoic should be indifferent towards, and which should never preclude the moral life. Kaempfer's condemnation of these groups contrasts nicely with his positive appraisal of the Japanese in general, who are willing to forego shame through suicide, and face execution valiantly. Although Kaempfer is less explicit on the regulated than the regulators, he clearly views the Japanese as the better stoics, whom can therefore be considered exemplary by Europeans.

\section{Conclusion}

To Kaempfer, the practices of Japanese law were more effective and fair than those back home. Japan served as an example were European assumptions did not hold. Where its policy could be criticized, he defended it with quotes and examples from authoritative European sources. Dionysius served as a textbook example of how a sovereign above the law was problematic, but with his positive experiences of Japan, Kaempfer tried to surpass these concerns, and support absolutism.

When it came to the regulation of foreigners, he was more negative, but by limiting his criticism to Nagasaki, and stressing the exceptional state of the city, this criticism could stand isolated from his positive assessment of Japan. It was mainly Scheuchzer, by linking these observations to statements on the peculiar jealousy of the Japanese, who broke this isolation, and turned the localized negativity into a critique of Japan in general.

In his assessment of the regulated, Kaempfer also shows his ideological leanings. Praising Japanese perseverance and suicide under intense circumstances, and criticizing Dutch submission, the book offered the Japanese population as an example to the Europeans, and shows that they still had much to learn, when it came to living the life of a Stoic. Here again, it was Scheuchzer who turned this praise into pity, making it a condemnation of Japanese practices.

In The History of Japan, Kaempfer's statements on Tokugawa go beyond mere observation. Although 'othering' took place, it does not fit the literature's description of the act, as it was not condescending. To Kaempfer, Japan did not serve as a case study of Western superiority, but as a highly developed country in its own right, whose state of affairs was exemplary. Contrary to his native Germany, which was embroiled in war, Japanese society was peaceful and united. Noting the differences between Europe and Japan served as a way to reflect on European ideas, support his personal political beliefs, and criticize those conventional theories, which went against these beliefs. Kaempfer did not merely seek to describe Japan - he educated Europe. 


\section{Bibliography}

Bodart-Bailey, B.M. (1988). Kaempfer Restor'd. Monumenta Nipponica 43(1), 1-33.

Bodart-Bailey, B.M. (1995). Writing 'The History of Japan'. In B.M. Bodart-Bailey \& D. Massarella (Eds.). The Furthest Goal: Engelbert Kaempfers Encounter with Tokugawa Japan (pp. 17-43). Folkestone: Japan Library.

Bodart-Bailey, B.M. (1999). Translator's Introduction. In E. Kaempfer. Kaempfer's Japan: Tokugawa Culture Observed (pp. 1-21). Honolulu: University of Hawai Press.

Brakensiek, S. (2002). Political judgement between empirical experience and scholarly tradition: Engelbert Kaempfer's report on Persia (1684-85). Medieval History Journal 5(2), 223-246.

Bruijn, I. (2009). Chirurgijns op de schepen van de Verenigde Oost-Indische Compagnie. Tijdschrift voor Medisch Onderwijs 28(4), 180-182.

Haberland, D. (1996). Engelbert Kaempfer 1651-1716: A Biography. London: British Library.

Kaempfer, E. (1727). The History of Japan, giving an Account of the ancient and present State and Government of that Empire; of Its Temples, Palaces, Castles and other Buildings; of its Metals, Minerals, Trees, Plants, Animals, Birds and Fishes; of The Chronology and Succession of the Emperors, Ecclesiastical and Secular; of The Original Descent, Religions, Customs, and Manufactures of the Natives, and of their Trade and Commerce with the Dutch and Chinese. Together with a Description of the Kingdom of Siam. (J.C. Scheuchzer, Trans.) London: Published for translator.

Kaempfer, E. (1729). De Beschryving van Japan: behelsende een verhaal van den ouden en tegenwoordigen staat en regeering van dat ryk: van deszelfs tempels, paleysen, kasteelen en andere gebouwen: van deszelfs metalen, mineralen, boomen, planten, dieren, vogelen en visschen: van de tydrekening, en opvolging van de geestelyke en wereldlyke keyzers: vam de oorfprondelyke afstamming, godsdiensten, gewoonten en handwerkselen der inboorllingen, en van hunnen koophandel met de Nederlanders en de Chineesen: Benevens eene beschryving van het koningryk Siam. 's- Gravenhage: P. Gosse/ J. Neaulme \& Amsterdam: Balthasar Lakeman.

Kaempfer, E. (1999). Kaempfer's Japan: Tokugawa Culture Observed. (B.M. Bodart-Bailey, Trans. and Ed.). Honolulu: University of Hawai Press. 
Kaempfer, E. (2001). Heutiges Japan. (Vol. 1/1). (W. Michel \& B.J. Terwiel, Trans.). München: ludicium.

Massarella, D. (1995)., The History of The History: The Purchase and Publication of Kaempfer's 'History of Japan'. In B.M. Bodart-Bailey \& D. Massarella (Eds.). The Furthest Goal: Engelbert Kaempfers Encounter with Tokugawa Japan (pp. 96-131). Folkestone: Japan Library.

Michel, W. (2000). His Story of Japan: Engelbert Kaempfer's Manuscript in a New Translation. Monumenta Nipponica, 55(1), 109-120.

Michel, W. (2010). Johann Caspar Scheuchzer (1702-1729) und die Herausgabe der 'History of Japan'. Asiatische Studien/ Études Asiatiques 64(1), 101-137.

Rietbergen, P.J.A.N. (2002). Japan: the 'un-knowable' other'? Two seventeenth-century European models for 'knowing' Japan. Lias, 29(1), 63-80.

Rietbergen, P.J.A.N. (2003). Japan verwoord. Nihon door Nederlands ogen, 1600-1799. Amsterdam: Hotei.

Rist, J.M. (1969). Stoic philosophy. Cambridge: Cambridge University Press.

Said, E. (1978/2003). Orientalism (5 ${ }^{\text {th }}$ ed.). London: Penguin.

Seidler, M.J. (1983). Kant and the Stoics on Suicide. Journal of the History of Ideas, 44(3), 429-453.

Thompson, C. (2011). Travel Writing. London - New York: Routledge.

Van de Bilt, A.M. (1946). Lipsius' De Constantia en Seneca. Nijmegen: Centrale Drukkerij.

Van der Velde, P. (1995). The Interpreter Interpreted: Kaempfer's Japanese Collaborator Imamura Genemon Eisei. In In B. M. Bodart-Bailey \& D. Massarella (Eds.). The Furthest Goal: Engelbert Kaempfers Encounter with Tokugawa Japan (pp.44-58). Folkestone: Japan Library.

Van Gelder, R. (1997). Het Oost-Indisch avontuur. Duitsers in dienst van de VOC (1600-1800). Nijmegen: SUN.

Westlake, H.D. (1959). Dionysius of Syracuse. The Classical Review 9(3), 269-271. 


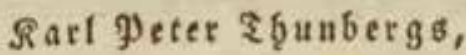

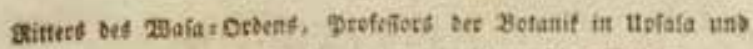

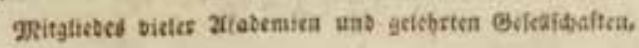

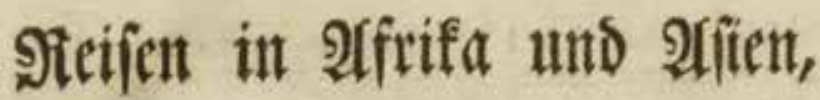

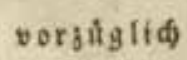

\section{in $\mathfrak{A}_{\mathrm{a}} \mathrm{a} n$,}

$$
\begin{aligned}
& \text { nob }
\end{aligned}
$$

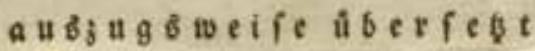

\section{Rurt Eprengel,}

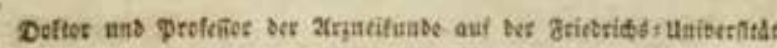

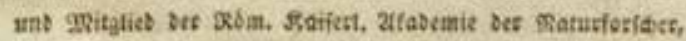

$$
\text { at } \mathrm{nb}
$$

mit Srmerfungen begleitet

Den

Jobann Feinbolb Forfter,

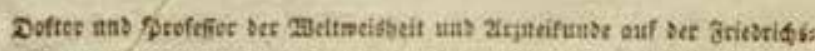

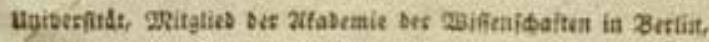

$$
\text { 14. f. } 18 \text {, }
$$

Berlin, 1792 .

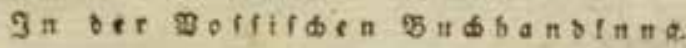

